\title{
A comparison of bird communities in the anthropogenic and natural-tree fall gaps of a reduced-impact logged subtropical forest in Bolivia
}

\author{
ADAM FELTON, JEFF T. WOOD, ANNIKA M. FELTON, BENNETT A. \\ HENNESSEY and DAVID B. LINDENMAYER
}

\begin{abstract}
Summary
We studied bird community composition and abundance within four vegetation and disturbance categories located within selectively logged and unlogged forest in a Bolivian subtropical lowland forestry concession. The logged forest was subject to reduced-impact logging between $I$ and 4 years prior to our study. The four categories were: 1) 'gap' points possessing natural or anthropogenic tree-fall gaps; 2) 'target' points with one of five commercial tree species of harvestable size; 3 ) 'future' points possessing a commercial tree below harvestable size; and 4) 'non-target' points not possessing harvestable tree species. The bird community composition of logging gaps significantly differed from that found within natural tree-fall gaps in the unlogged forest $(P<0.05)$. Species richness was higher in natural tree-fall gaps than in anthropogenic gaps. Furthermore, a higher proportion of disturbance sensitive species were associated with natural-tree fall gaps, whereas a higher proportion of disturbance tolerant species were associated with anthropogenic gaps. No significant difference was detected in the bird community composition for the other three vegetation categories surveyed. We discuss the conservation and silvicultural repercussions of these results.
\end{abstract}

Keywords: Birds, gaps, reduced-impact logging, vegetation structure

\section{Introduction}

Tropical forests are the most species-rich of all terrestrial ecosystems (Turner 1996), and their preservation will be an integral component of successful global conservation efforts (Groombridge and Jenkins 2002). Of the anthropogenic processes threatening tropical forests, there is increasing evidence that selective logging can rival deforestation in the total amount of tropical forested area being degraded (Asner et al. 2005). Selective logging is the dominant form of timber extraction in the tropics (Rametsteiner and Simula 2003), and involves the periodic extraction of large, and well-formed representatives of a forest's commercially valuable tree species (Johns 1988). The extent to which 'selective logging' degrades forest structure varies considerably, depending on extraction rates and the extent of collateral damage to the residual stand (Johns 1988). As a term, 'selective logging' therefore represents a continuum of anthropogenic disturbance, ranging from deforestation at one extreme to extensive canopy and vegetation structure retention at the other (van Soest 1998). It is expected that 
somewhere along this continuum, prescriptions for selective logging can be developed that successfully combine economically viable levels of timber extraction with biodiversity conservation (Pinard and Putz 1996). Reduced-impact logging (RIL) is being developed in response to this need.

RIL is a form of selective logging increasingly employed in tropical forests. It incorporates a variety of techniques aimed at lowering levels of damage to the residual stand (Putz et al. 2001). These include directional felling, pre-harvest vine cutting, and preliminary inventories to reduce the number and density of logging roads (Heinrich 1995). Recent studies suggest that reducedimpact logging of tropical forests causes less damage to forest structure than conventional selective logging techniques (Asner et al. 2004; Huth et al. 2004). However, reduced-impact logging is still a form of commercial forestry that can disturb vegetation structure (Jackson et al. 2002), and thus impact on some forest dependent species (Bojanic and Bulte 2002; Dauber et al. 2005), such as birds.

Bird community composition is strongly determined by vegetation structure (MacArthur et al. 1966; Gilmore 1985; Wiens 1992). The structural characteristics of forest plant communities support some of the vital requirements of 'habitat' for birds, including those for reproduction, shelter, predator avoidance and foraging efficiency (Holling 1992). Disturbance to vegetation structure does not however necessarily equate with loss of habitat for forest dependent bird species (Lindenmayer and Fischer 2006). This is because disturbance is an integral part of forest ecosystems (Schemske and Brokaw 1981; Attiwill 1994), and under natural conditions can vary spatially and temporally from frequent low intensity disturbances at the scale of individual tree-falls, to infrequent landscape scale high intensity events (eg. fires, severe storms) that can significantly alter entire stands (Coates and Burton 1997). Each bird species will react differently to forest disturbance depending (in part) on its habitat specialization, foraging behaviour, diet adaptability and physiological sensitivity to microclimatic changes (Thiollay 1992; Barlow and Peres 2004; Wunderle et al. 2005; Wunderle et al. 2006; Gray et al. 2007). For instance, tree falls, and the gaps they create, represent a source of numerous relatively small scale disturbances within a forest that are simultaneously a source of habitat for some birds, and a loss of habitat for others. For this reason, studies of bird species' responses to tropical forest disturbance have reported negative, positive or neutral impacts on population size and/or demographics, depending on the extent of disturbance and the associated impact on the availability of habitat for the species being considered (Hill and Hamer 2004).

The most species-rich avian communities in the world are found in Neotropical forests (Ridgely and Tudor 1994; Turner 1996). Research findings from conventional selective logging (Mason 1996), and other forms of forest disturbance within the Neotropics (Aleixo 1999) suggest that it will be those bird species closely associated with specific vegetation types targeted by logging which will be most likely to decline in population size, or express negative demographic responses to RIL (Thiollay 1997). For example, species that typically decline from forests subjected to conventional selective logging are often restricted to specific vegetation types, such as the understorey in tall forests (Canaday 1996; Thiollay 1997). In contrast, those species which are favoured by anthropogenic disturbance are generally ubiquitous even in secondary forests (Thiollay 1997; Aleixo 1999).

Previous research on vegetation structure within a reduced-impact logged forest in the subtropical lowland province of Santa Cruz, Bolivia, demonstrated that logging gaps created by reduced-impact logging were not the anthropogenic equivalents of natural tree-fall gaps (Felton et al. 2006). In this paper we assess whether the bird communities of a reduced-impact logging concession differ; i) within anthropogenic and natural tree-fall gaps, and ii) within comparable vegetation categories of the harvested and unharvested areas of the concession. We discuss our results in relation to current expectations regarding the compatibility of RIL associated disturbance with biodiversity maintenance. 


\section{Methods}

\section{Site description}

Our study area was located in the lowland subtropical humid forest of the Guarayos Forest Reserve, Department of Santa Cruz, Bolivia. Research was conducted in the 100,000 ha forestry concession "La Chonta". This is owned and managed by Agroindustria Forestal La Chonta (509000 to 545000 easting, 8275500 to 824900 northing; Figure 1 ). The forest has an average elevation of $320 \mathrm{~m}$ (range 230-39om). The soils consist of oxisols, ultisols, and inceptisols (Park et al. 2005). The mean annual temperature is $25^{\circ} \mathrm{C}$ with a mean annual precipitation of approximately $1,560 \mathrm{~mm}$. The region experiences a distinct dry season from May to October. The entire concession was subjected to legal and illegal selective logging of Mahogany (Swietenia macrophylla), and Spanish Cedar (Cedrela odorata) 10-25 years prior to this study. The concession was certified by SmartWood in 1998.

\section{Harvesting procedure}

Approximately 2,500 ha was harvested each year over three contiguous 850 ha blocks $(\sim 4 \mathrm{~km}$ $\times 2 \mathrm{~km}$ ), yielding $50,000 \mathrm{~m}^{3}$ of timber annually. Eighteen commercial tree species were harvested during the time of this study (2003-2004) including Ficus boliviana, Hura crepitans, Terminalia oblonga, Pseudolmedia laevis, Cariana ianeirensis, and C. estrellensis. Average harvest intensity was approximately 4 trees $\mathrm{ha}^{-1}$ (Jackson et al. 2002). The forestry company Agroindustria Forestal La Chonta conducts inventories of harvestable trees one year prior to logging. The minimum size for harvest is $50 \mathrm{~cm}$ diameter at breast height (dbh) for all species except $F$. boliviensis and $H$. crepitans, which are harvested above $70 \mathrm{~cm} \mathrm{dbh}$. One in five harvestable trees is required by law to be left as a seed tree. During pre-harvesting inventory, trees selected for felling are cleared of all vines on the bole.

The forestry company uses a 'fishbone' harvesting strategy with a single primary north-south road bisecting each 850 ha block. Skid trails are located 100-150 $\mathrm{m}$ apart and run in an east-west direction on either side of the primary road. Chainsaw teams trained in directional felling

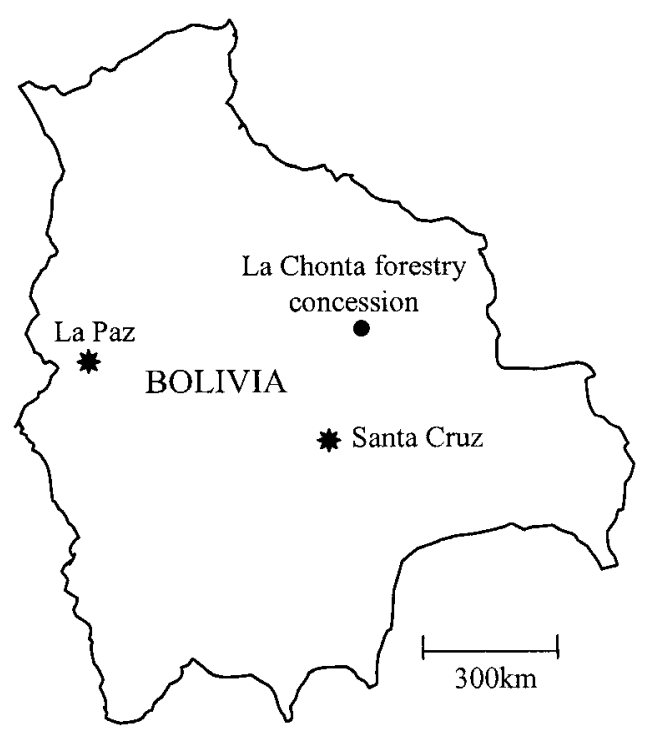

Figure 1. Map of Bolivia with approximate location of the la Chonta forestry concession indicated within the department of Santa Cruz. 
techniques try to reduce damage to the residual stand during felling. Removal and loading of boles is conducted using rubber-tired skidders to reduce soil compaction. It is intended that blocks be re-cut in 25-30 years, and unlogged areas of the concession were destined to be logged from 2004-2007.

\section{Survey design}

Because selective logging disproportionately disturbs forest with commercial densities of harvestable trees, a stratified-random sampling design was used which incorporated commercial tree species occurrence, vegetation height, and disturbance type. This design increased the likelihood that logged and unlogged survey points were appropriate for comparison, accounted for natural variation in vegetation structure, and enabled us to distinguish between different disturbance types. The four vegetation categories were: 1 . 'target' points (T) with vegetation height $>20 \mathrm{~m}$ and possessing one of five commercial tree species of harvestable size (Ficus boliviensis, Hura crepitans, Cariniana estrellensis, C. ianeirensis, Terminalia oblonga); 2. 'future' points (F) from $12-20 \mathrm{~m}$ in height and possessing an individual of the aforementioned five species not yet of harvestable size but above $30 \mathrm{~cm} \mathrm{dbh}$; 3 . 'non-target' points (N) of less than $12 \mathrm{~m}$ in height and not possessing commercial trees above $10 \mathrm{~cm} \mathrm{dbh}$; and 4 . 'gap' points (G) possessing a tree-fall gap caused by the felling of a tree (in the harvested blocks) or a natural gap created by a tree (in the unlogged blocks) of greater than $50 \mathrm{~cm} \mathrm{dbh}$. In the logged forest, the 'target' category was represented by seed trees left by loggers to aid regeneration. Trees not harvested due to undesirability (eg. insufficient bole length or malformation) were not included in this category. In total, 96 points was surveyed, represented by 24 points of each of the four vegetation categories equally divided between the logged and unlogged areas of the concession (Figure 2).

We conducted vegetation structure and floristic surveys at all survey points during June and July 2004. At each point, a $20 \mathrm{~m} \mathrm{x} 20 \mathrm{~m}$ quadrat was marked within which we quantified aspects of canopy cover, canopy height, understorey density, tree species diversity, basal area, and other aspects of vegetation physiognomy and floristics. For details of vegetation sampling design see Felton et al. (2006).

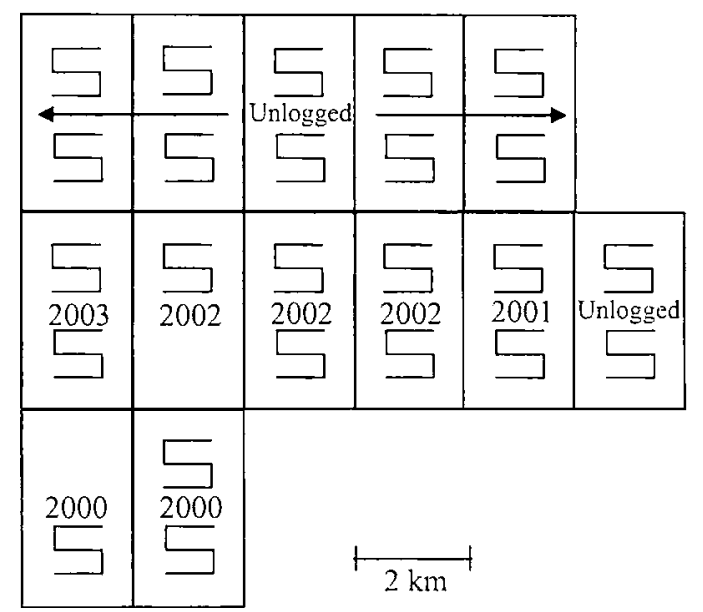

Figure 2. Schematic diagram representing relative location of reduced-impact logged blocks (labeled with year of harvest) and unlogged sites used in this study within the La Chonta concession, department of Santa Cruz, Bolivia. The ' $\mathrm{S}$ ' symbol represents transects cut within each block. Four points, comprising one representative of each of the four vegetation categories, was place along each of three east/west transects of each ' $\mathrm{S}$ '. The east/west transects are $\sim_{1} \mathrm{~km}$ in length. Unlogged areas are to be harvested between 2004 and 2007. 


\section{Bird surveys}

At each of the 96 survey points, we used the point-count method of surveying bird species abundance. Only birds observed $<20 \mathrm{~m}$ from the observer were included in analyses, due to the need to couple bird species occurrences with vegetation categories. This relatively small radius was also used to minimize the potential for biases affecting the detectability of birds when surveying in habitats that vary substantially in vegetation structure (Verner 1981; Verner and Ritter 1988; Waide and Narins 1988; Petit et al. 1999). To reduce the effects of seasonal variation on bird abundance/presence, logged and unlogged areas were surveyed on alternate days. All survey points were located at least $300 \mathrm{~m}$ from the nearest other point, and at least $500 \mathrm{~m}$ from the edge of neighbouring treatment blocks. Surveys were conducted from December to February of the 2003-2004 wet season. One observer (A.F.) completed all surveys. Surveys began at first light (05h45-06hoo), and continued until approximately o7h3o. This period overlapped with 1 : the daily peak in bird vocal activity (pers. obs. A.F.), and more specifically 2: with the time period when those bird families that are sensitive to logging disturbance in the La Chonta concession are most active, and therefore most likely to be detected during surveys (Woltmann 2005). Each dawn survey consisted of visiting one point of each of the four habitat types. Each point was surveyed for 12 minutes. We included birds flushed from the survey point on approach by the observer, while birds flying over the survey area were not included in the analysis.

Due to the density of forest vegetation, most identifications were made acoustically, rather than visually. In addition to point counts, recordings of birds also were made using a Sony TCM 5000 tape-recorder that was attached to a Sennheiser ME66 microphone. These recordings were used as a supplement to field identification of vocalizing species. For unidentified species, symbolic representations of songs were noted. This was in addition to notes on the recording time, direction, and estimated distance to the call. This enabled the matching of subsequent identifications with abundance and distance information. Unknown recordings were identified using the CD-ROM Birds of Bolivia, 2.0 (Mayer 200o), or by an expert (B.H). Survey results were used as a crude surrogate of relative abundance, rather than as estimates of absolute density.

\section{Statistical analysis}

Bird species recorded only once during surveys were removed from analysis. We used correspondence analysis (Greenacre 1984) to reduce the dimensionality of each data set. Scores were obtained for the first three axes, which accounted for the majority of variation in the data. General linear regression (Timm and Mieczkowski 1997) was applied sequentially using each of these two axes to determine whether a given habitat category (eg. 'non-target') differed significantly in terms of bird community composition and abundance between the logged and unlogged habitats. Jaccard's index of similarity (Krebs 1998) was calculated to facilitate comparison with previous studies of logging impacts on tropical bird communities.

The Indicator Value (IV) procedure (Dufrêne and Legendre 1997) was used to test associations between individual bird species and anthropogenic or natural tree-fall gaps. IndVal is a percentage that ranges from o to 100 with the maximum value afforded when a species is present only in one habitat type and occupies all sites within that habitat. Higher IV values therefore indicate species which are more representative for the given habitat. A random reallocation procedure using 1,000 iterations was conducted to test the significant level of IndVal results $($ alpha $=0.05)$.

\section{Results}

During dawn point-count surveys, we identified approximately 1,150 birds, belonging to 123 species, representing 32 families. Of the four habitat categories, bird community composition 
and abundance significantly differed between logged and unlogged gaps (Table 1). 'Non-target', 'future target', and 'target' habitat categories were similar in terms of bird community composition and abundance between the logged and unlogged areas (Table 1). Logged and unlogged gaps had the lowest overlap in species composition of the four habitat categories as determined by the Jaccard index of similarity (Table 1 ). Species richness was higher in naturaltree fall gaps (Table 1). Structural characteristics of natural and anthropogenic tree fall gaps found in the logged and unlogged forests are presented in Table 2.

Results of the Indicator Value (IV) method are presented in Table 3 and 4. The twenty species with the highest IV score are listed in descending order of association with unlogged gaps (Table 3) and logged gaps (Table 4). Random reallocation permutations demonstrated that Black-faced Antthrush Formicarius analis is significantly more associated with natural tree-fall gaps than with anthropogenic gaps. IndVal scores are used to indicate the relative contribution of bird species to the established differences in bird community composition between anthropogenic and natural tree-fall gaps. Six of the 20 species with the highest IV association with the unlogged gaps were found to be significantly less abundant overall in the logged versus the unlogged areas of the La Chonta concession (Table 3). Three bird species exhibiting the opposite trend (i.e. with a significantly higher prevalence in the logged versus unlogged gaps) were among the 20 species with the highest IV association with the logged gaps (Table 4). Birds that were considered to exhibit a 'high' sensitivity to disturbance (Stotz et al. 1996), were more prevalent in natural-tree fall gaps $(50 \%$ of species) than in anthropogenic gaps $(20 \%$ of species). Birds that were considered to exhibit a 'low' sensitivity to disturbance (Stotz et al. 1996), were four times more prevalent in anthropogenic gaps ( $20 \%$ of species) than in natural-tree fall gaps ( $5 \%$ of species) (see Table 3 and 4 ).

\section{Discussion}

Natural tree-fall gaps supported higher bird species richness than anthropogenic tree-fall gaps. Bird community composition was also significantly different between natural tree-fall gaps and logging gaps in this RIL concession. Furthermore, $50 \%$ of those bird species which were more associated with natural tree-fall gaps are considered to be relatively 'vulnerable to human disturbance' as defined by (Stotz et al. 1996). This indicates that natural-tree fall gaps support species of higher conservation importance than anthropogenic gaps. We consider that two, potentially synergistic, causal processes may be driving these differences. First, fundamental differences in the type of habitat created by natural and anthropogenic gaps may be supporting different avian assemblages. Second, differences in the bird community composition and abundance of the surrounding residual stand may be leading to corresponding changes in the bird assemblages found within anthropogenic gaps. The distinction between these processes is primarily one of scale. Presence and abundance of individual bird species within a gap will be driven by such things as habitat selection, foraging behaviour, mating systems, and population

Table 1. General linear regression of the primary axis of correspondence analysis for bird community composition and abundance within habitat categories located in the logged and unlogged forests of the La Chonta concession, Department of Santa Cruz, Bolivia. Species richness and results from the Jaccard similarity index are also provided.

\begin{tabular}{|c|c|c|c|c|}
\hline \multirow{2}{*}{$\frac{\text { Habitat category }}{\text { Unlogged vs. Logged }}$} & \multicolumn{2}{|c|}{ Number of species } & \multirow{2}{*}{$\begin{array}{l}\text { Jaccard similarity } \\
\text { index }\end{array}$} & \multirow[t]{2}{*}{$P$ value } \\
\hline & Unlogged & Logged & & \\
\hline Gap & 56 & 49 & 0.42 & $<0.05$ \\
\hline Non-target & 51 & 43 & 0.45 & n.s. \\
\hline Future target & 50 & 48 & 0.48 & n.s. \\
\hline Target & 56 & 48 & 0.46 & n.s. \\
\hline
\end{tabular}


Table 2. Selected structural measurements (mean $+/-\mathrm{SE}$ ) distinguishing amongst 22 variables relating to vegetation structure within natural and anthropogenic gaps in the reduced impact logged area of the subtropical humid forests of the la Chonta forestry concession, Santa Cruz, Bolvivia. S.E. stands for standard error. Modified from Felton et al. (2006).

\begin{tabular}{|c|c|c|}
\hline \multirow[t]{2}{*}{ Structural measurements } & \multirow{2}{*}{$\frac{\text { Unlogged }}{\text { Mean }+/- \text { SE }}$} & \multirow{2}{*}{$\frac{\text { Logged }}{\text { Mean }+/- \text { SE }}$} \\
\hline & & \\
\hline \# of tree species / 0.04 ha & $8.4+/-0.5$ & $7.7+1-0.5$ \\
\hline \# of trees / 0.04 ha & $14+/-1$ & $11.5+/-0.7$ \\
\hline Canopy height (m) & $9.8+1-0.8$ & $11+/-0.8$ \\
\hline Canopy cover (\%) & $91+/-1.1$ & $88+/-1.5$ \\
\hline \# of poles / 0.04 ha & $24.1+/-1.5$ & $24.5+/-1.9$ \\
\hline Leaf litter depth & $2.1+/-0.1$ & $1.9+/-0.1$ \\
\hline Fern $\%$ cover & $28.3+/-2.7$ & $23.9+1-2.3$ \\
\hline Basal area sq. m / 0.04 ha & $0.5+/-0.1$ & $0.5+/-0.1$ \\
\hline Leaf litter \% cover & $80+/-1.6$ & $79+/-1.8$ \\
\hline Erythrochiton fallax \% cover & $5+/-2.3$ & $1+/-0.7$ \\
\hline Palm \% cover & $1.4+/-0.5$ & $2.2+/-0.6$ \\
\hline \# Flower plants / 0.04 ha & $15.2+/-3$ & $11.5+1-3$ \\
\hline \# fruiting plant / 0.04 ha & $1+/-0.3$ & $0.4+/-0.1$ \\
\hline Seedling $\%$ cover & $13 \cdot 3+/-1.7$ & $23.6+/-2.2$ \\
\hline Understorey density $(\mathrm{O}-20)$ & $5.3+/-0.5$ & $6.8+/-0.5$ \\
\hline \# of palms / 0.04 ha & $0.7+/-0.5$ & $1.1+/-0.8$ \\
\hline Vine high \% cover & $10.7+/-2.1$ & $3.8+/-1$ \\
\hline Bare ground \% cover & $4.3+/-0.8$ & $3 \cdot 3+/-0.8$ \\
\hline Vine low $\%$ cover & $19.9+/-2.7$ & $13.7+/-1.9$ \\
\hline Heliconia spp. \% cover & $15+/-2.5$ & $20+/-3.2$ \\
\hline Gap size $\left(\mathrm{m}^{2}\right)$ & $405+/-52.4$ & $638+1-76.9$ \\
\hline
\end{tabular}

dynamics. These responses will be influenced both by conditions experienced at the scale of the gap, and at the larger spatial scale of the surrounding forest (Mitchell et al. 2006). We discuss these two causal processes below.

\section{Within gap processes}

Gaps created by reduced-impact logging practices are quantifiably different from gaps caused by natural processes. Logging gaps were larger in size, differed in terms of microclimatic variables, were significantly lower in understorey density, and differed in the composition of regenerating vegetation (See Table 2; Jackson et al. 2002; Felton et al. 2006). Differences in bird community composition and abundance within logging gaps may therefore be the direct result of either microclimatic differences, and/or the associated changes in vegetation structure and phylogeny (Hasui et al. 2007).

Neotropical species that evolved in the relatively stable understories of closed-canopy forest can be directly intolerant of the altered microclimates within larger gaps (Canaday 1996; Stratford and Robinson 2005). This may be due to physiological and behavioral sensitivity to increased light conditions (Stratford and Robinson 2005). For example, the Black-faced Antthrush, a ground antbird belonging to the family Formicariidae, occurred in over $40 \%$ of unlogged gaps, but was never detected in the logging gaps. Members of this family are known to be intolerant of disturbance (Barlow et al. 2002; Ferraz et al. 2003), particularly within habitats experiencing levels of irradiance above a threshold level (Sekercioglu et al. 2002). The large canopy openings created by logging gaps in the La Chonta concession means that these areas are 


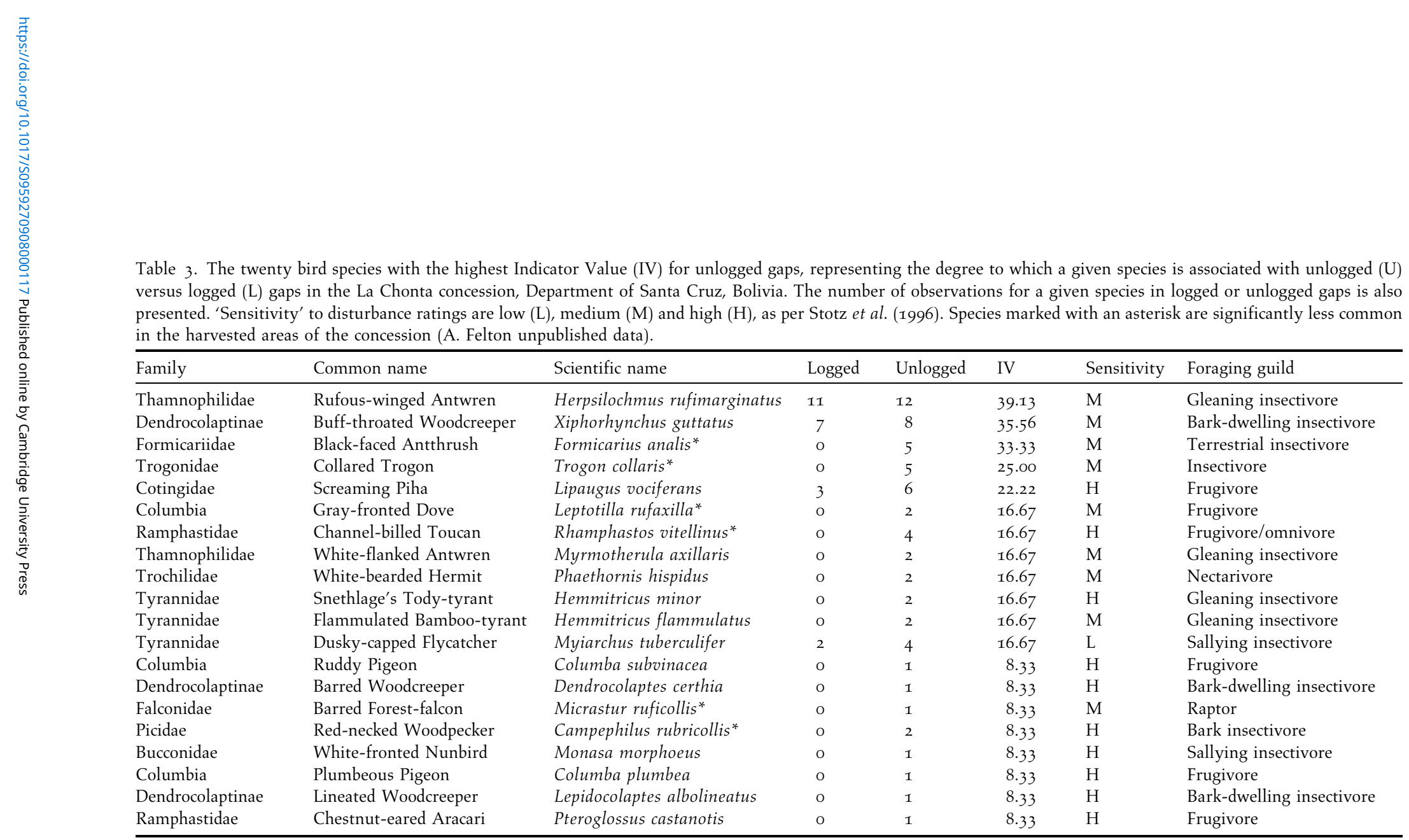


Table 4. The twenty bird species with the highest Indicator Value (IV) for logged gaps, representing the degree to which a given species is associated with logged (U) versus unlogged (L) gaps in the La Chonta concession, Department of Santa Cruz, Bolivia. The number of observations for a given species in logged or unlogged gaps is also presented. 'Sensitivity' to disturbance ratings are low (L), medium (M) and high (H), as per Stotz et al. (1996). Species marked with an asterisk are significantly less common in the harvested areas of the concession (A. Felton unpublished data).

\begin{tabular}{|c|c|c|c|c|c|c|c|}
\hline Family & Common name & Scientific name & Logged & Unlogged & IV & Sensitivity & Foraging guild \\
\hline Tyrannidae & Forest Elaenia & Myiopagis garmardii & 9 & 5 & 42.86 & M & Sallying insectivore \\
\hline Thamnophilidae & Plain Antvireo & Dysithamnus mentalis & 8 & 3 & $42.4^{2}$ & M & Gleaning insectivore \\
\hline Thraupinae & Red-crowned Ant-tanager & Habia rubica & 7 & 4 & 37.12 & $\mathrm{H}$ & Insectivore/omnivore \\
\hline Cardinalinae & Blue-black Grosbeak & Cyanocompsa cyanoides & 4 & 1 & 26.67 & M & Omnivore \\
\hline Dendrocolaptinae & Cinnamon-throated Woodcreeper & Dendrexetastes rufigula & 4 & o & 25.00 & $\mathrm{H}$ & Gleaning insectivore \\
\hline Motmotidae & Blue-crowned Motmot & Motmotus motmota & 3 & o & 25.00 & M & Sallying insectivore \\
\hline Thamnophilidae & Black-throated Antbird & Myrmeciza atrothorax* & 3 & o & 25.00 & $\mathrm{~L}$ & Gleaning insectivore \\
\hline Tinamidae & Little Tinamou & Crypturellus soui* & 5 & 2 & 23.81 & $\mathrm{~L}$ & Terrestrial granivore \\
\hline Tinamidae & Undulated Tinamou & Crypturellus undulatus & 4 & 1 & 20.00 & $\mathrm{~L}$ & Terrestrial granivore \\
\hline Parulinae & Golden-crowned Warbler & Basileuterus culicivorus* & 3 & 1 & 18.75 & M & Insectivore/omnivore \\
\hline Furnariinae & Buff-throated foliage-Gleaner & Automolus ochrolaemus & 3 & o & 16.67 & M & Gleaning insectivore \\
\hline Picidae & White-throated Woodpecker & Piculus leucolaemus & 2 & o & 16.67 & M & Bark-dwelling insectivore \\
\hline Thamnophilidae & Spot-backed Antbird & Hylophylax navia & 2 & o & 16.67 & $\mathrm{H}$ & Gleaning insectivore \\
\hline Trochilidae & Reddish Hermit & Phaethronis ruber & 4 & 2 & 16.67 & M & Nectarivore \\
\hline Tyrannidae & Yellow-margined Flycatcher & Tolmomyias assimilis & 2 & o & 16.67 & $\mathrm{H}$ & Sallying insectivore \\
\hline Emberizinae & Pectoral Sparrow & Arremon taciturnus & 3 & 1 & 12.50 & M & Omnivore \\
\hline Pipridae & Firey-capped Manakin & Machaeropterus pyrocephalus & 3 & 1 & 12.50 & M & Frugivore \\
\hline Dendrocolaptinae & Olivaceous Woodcreeper & Sittasomus griseicapillus & 2 & 1 & 11.11 & M & Bark-dwelling insectivore \\
\hline Trogonidae & Black-tailed Trogon & Trogon melanurus & 2 & 1 & 11.11 & M & Omnivore \\
\hline Bucconidae & Gray-cheeked Nunlet & Nonnula ruficapilla & 1 & $\mathrm{o}$ & 8.33 & $\mathrm{~L}$ & Sallying insectivore \\
\hline
\end{tabular}


more likely to have passed a microclimatic toleration-threshold for bird species such as Blackfaced Antthrush.

These microclimatic conditions, and the associated flush of dense vegetation, potentially result in the altered availability, or accessibility, of different types of invertebrate prey (Didham et al. 1996). As insectivores use a variety of different foraging methods and capture prey at varying heights and on different substrates, it is not surprising to find differences in the relative composition of insectivorous species (belonging to different foraging guilds) within logging gaps and gaps created by natural tree falls (see Tables 3 and 4 ). These differences may be further accentuated by pre-harvest liana cutting. As lianas provide a distinct foraging substrate, those birds which are obligate or facultative liana foragers, may be detrimentally effected by this practice (Barlow et al. 2006). As the practice of pre-harvest liana cutting is successfully reducing liana loads in logging gaps (Felton et al. 2006), it is possible that this practice influences the availability of suitable habitats within natural and anthropogenic gaps.

Research by Hasui et al. (2007) suggests that the abundance of obligate frugivorous bird species is strongly influenced by the availability of key plant species providing the necessary fruit production. Conversely, bird species with more insectivorous/generalist diets, may be primarily influenced by variation in habitat structure, which can alter both the availability of prey items, and the bird species' foraging efficiency (Hasui et al. 2007). There was a distinct difference in the number of bird species belonging to each of these guilds in the anthropogenic and natural tree fall gaps.

Natural-tree fall gaps supported higher numbers of frugivorous species, whereas anthropogenic tree-fall gaps supported higher numbers of insectivore/omnivores and omnivores. The increased numbers of insectivore/omnivores and omnivores within anthropogenic tree-fall gaps may arise due to associated changes in vegetation structure resulting in increased availability of perches, prey, or a general improvement in prey visibility (Cody 1980). For frugivorous birds, the harvesting of fruit-bearing timber tree species such as Ficus boliviana, and Pseudolmedia laevis (Woltmann 2003), may be contributing to their decreased abundance in anthropogenic tree-fall gaps. Although there was an expectation that increased light levels within logging gaps will result in a post-harvest fruiting bloom (Schemske and Brokaw 1981; Lambert 1992; Wunderle et al. 2006), either this did not occur, or it was insufficient to compensate for the removal of fruit bearing tree species (Table 2).

Logging gaps in La Chonta concession did however have a greater percentage of plants in flower than their natural counterparts in the unlogged forest (Felton et al. 2006). Certain avian guilds (eg. nectarivores) may therefore increase in abundance following selective logging due to the increased availability of nectar in logging gaps, and other areas of canopy discontinuity (Mason 1996). Part of the altered bird species community composition and abundance in this study (eg. the Reddish Hermit Phaethornis ruber) may be a direct response to differences in the availability of nectar.

\section{Influence of conditions in the surrounding forest}

We did not detect significant differences in bird communities within the 'target', 'non-target', and 'future' vegetation categories used in this study. However, as these vegetation categories were specifically placed within areas of the forest not directly altered by logging, the only potential logging associated disturbance in these treatments would be of an indirect nature. Comparison of understorey vegetation within these vegetation categories between the unlogged forest and the residual stand of the harvested forest, suggests that it takes four years or more before nearby canopy disturbance could alter regeneration patterns of understorey vegetation within adjacent undisturbed residual stand (A. Felton unpubl. data). Prior to this elapsed time, any differences in understorey vegetation appear to be within the range of natural habitat heterogeneity, and therefore do not appear to be altering bird community composition at this scale of assessment. 
Logging-related disturbance throughout the harvested areas of the concession may nevertheless influence the presence and abundance of at least some species within natural and anthropogenic gaps. Several species found at significantly higher overall abundance in the unharvested blocks (see Table 3), were found only within natural tree-fall gaps in the unlogged forest in this study. A similar trend was observed, for example, for the Black-throated Antbird (Myrmeciza atrothorax). This species was significantly more abundant in the harvested areas of the concession, and was only found within logging gaps of the harvested areas of the concession in this study. This indicates that conditions experienced at the scale of the residual stand or surrounding unlogged forest may contribute to differences in bird community composition within anthropogenic and natural tree-fall gaps.

For example, the Channel-billed Toucan (Ramphastos. vitellinus) is a primarily frugivorous canopy feeder (Remsen et al. 1993; Galetti et al. 2000) that moves across territories of approximately 40-50 ha in the Peruvian Amazon (Terborgh et al. 1990). Toucan movements are thought to be largely dictated by their need to follow the availability of fruit (Graham 2001). In the La Chonta concession, many of the harvested timber trees are also important fruit sources (Mostacedo and Fredericksen 1999; Park et al. 2005). The reduced abundance of Channel-billed Toucan within the logging gaps of the harvested areas of the concession is therefore likely to result from concession-wide reductions in fruiting tree resources. This may explain the absence of the Channel-billed Toucan from logging gaps in the harvested areas of the concession, rather than processes operating at the scale of conditions experienced within a particular gap.

\section{Management implications}

Current silvicultural practices are creating gaps significantly larger than their naturally formed counterparts in the unlogged forests of the concession. These anthropogenic gaps are unlikely to provide conditions favourable to the physiological adaptations of some understorey avian species; or beneficial to the regeneration of some commercial tree species (see Felton et al. 2006). The end result was that anthropogenic tree-fall gaps provided habitat for fewer species in general, and more importantly, fewer species considered sensitive to human disturbance. Reducing the extent of canopy disturbance where possible, and limiting the commercial harvest of potential keystone fruit resources (e.g. Ficus boliviana), may concomitantly address concerns regarding the long-term sustainability of timber production (Pariona et al. 2003), and the biodiversity maintenance capacity of this concession.

We support calls for forest management to be as consistent as possible with natural disturbance processes (Lindenmayer and McCarthy 2002; Messier and Kneeshaw 2003). However, we also reiterate the views expressed by Manning et al. (2004), who warned against the temptation to substitute what we perceive as habitat, with the "Umwelt" or the world as perceived by the species being considered (Manning et al. 2004). Gaps created by logging activities do not necessarily represent habitat to species occurring in natural gaps (Thiollay 1992). Despite the superficial resemblance of RIL gaps, to gaps caused by natural tree falls (Whitman et al. 1998), changes in bird community composition and abundance within anthropogenic gaps in this study suggest that the two disturbance processes are not interchangeable. These differences are directly relevant to those considering the compatibility of tropical RIL concessions with biodiversity maintenance.

\section{Acknowledgements}

This project was supported through the generous financial assistance of the American Ornithology Union, Sennheiser Australia, and the Lincoln Park Zoo. We thank the personnel of IBIF, Agroindustria Forestal La Chonta Ltd., Proyecto de Manejo Forestal Sostenible (BOLFOR), and Birdlife Bolivia (Armonia) for providing logistical support, especially Marielos 
Peña and Todd Fredericksen. Eugenio Mercado provided integral assistance during all phases of the field work and the advice of Ross Cunningham greatly contributed to the design of this project. We are grateful for the contribution of two anonymous reviewers who improved an earlier draft of this manuscript. Finally, we thank the Australian Red Cross without whom this project could not have been completed. All research was approved by the relevant authorities and this study was conducted within the ethical guidelines of Australia and Bolivia.

\section{References}

Aleixo, A. (1999) Effects of selective logging on a bird community in the Brazilian Atlantic forest. The Condor 101: 537-548.

Asner, G. P., Keller, M. and Pereira, R. et al., (2004) Canopy damage and recovery after selective logging in Amazonia: Field and satellite studies. Ecol. Applic 14: $\mathrm{S}_{2} 80-\mathrm{S}_{298}$.

Asner, G. P., Knapp, D. E. and Broadbent, E. N. et al., (2005) Selective logging in the Brazilian Amazon. Science 310: 480-482.

Attiwill, P. M. (1994) The disturbance of forest ecosystems - the ecological basis for conservative management. Forest Ecol. Manage 63: 247-300.

Barlow, J., Haugaasen, T. and Peres, C. A. (2002) Effects of ground fires on understorey bird assemblages in Amazonian forests. Biol. Conserv. 105: 157-169.

Barlow, J. and Peres, C. A. (2004) Avifaunal responses to single and recurrent wildfires in Amazonian forests. Ecol. Applic. 14: 1358-1373.

Barlow, J., Peres, C. A. and Henriques, L. M. P. et al., (2006) The responses of understorey birds to forest fragmentation, logging and wildfires: An Amazonian synthesis. Biol. Conserv. 128: 182-192.

Bojanic, A. and Bulte, E. H. (2002) Financial viability of natural forest management in Bolivia: environmental regulation and the dissipation and distribution of profits. Forest Policy and Economics 4: 239-150.

Canaday, C. (1996) Loss of insectivorous birds along a gradient of human impact in Amazonia. Biol. Conserv. 77: 63-77.

Coates, K. D. and Burton, P. J. (1997) A gapbased approach for development of silvicultural systems to address ecosystem management objectives. Forest Ecol. Manage. 99: 337-54.
Cody, M. L. (1980) Species packing in insectivorous bird communities: Density, diversity and productivity. Pp. 1071-1077 in R. Nohring, ed. Acta XVII Congressus Internationalis Ornithologici. Berlin: Verlag Der Deutschen OrnithologenGesellschaft.

Dauber, E., Fredericksen, T. S. and Pena, M. (2005) Sustainability of timber harvesting in Bolivian tropical forests. Forest Ecol. Manage. 214: 294-304.

Didham, R. K., Ghazoul, J., Stork, N. E. and Davis, A. (1996) Insects in fragmented forests: A functional approach. Trends Ecol. Evol. 11: 255-26o.

Dufrêne, M. and Legendre, P. (1997) Species assemblages and indicator species: The need for a flexible asymmetrical approach. Ecol. Monogr. 67: 345-366.

Felton, A., Felton, A. M. and Wood, J. et al., (2006) Vegetation structure, phenology, and regeneration in the natural and anthropogenic tree-fall gaps of a reducedimpact logged subtropical Bolivian forest. Forest Ecol. Manage. Accepted August 2006.

Ferraz, G., Russell, G. J., Stouffer, P. C., Bierregaard Jr, R. O., Pimm, S. L. and Lovejoy, T. E. (2003) Rates of species loss from Amazonian forest fragments. Proc. Natl. Acad. Sci. USA 100: 14069-73.

Galetti, M., Laps, R. and Pizo, M. A. (200o) Frugivory by toucans (Ramphastidae) at two altitudes in the Atlantic forest of Brazil. Biotropica 32: 842-50.

Gilmore, A. M. (1985) The influence of vegetation structure on the density of insectivorous birds. Pp. 21-31 in A. Keast, H. F. Recher, H. A. Ford and D. A. Saunders, eds. Birds of eucalypt forests and woodlands: ecology, conservation, and management. Sydney: Surrey Beatty \& Sons. 
Graham, C. H. (2001) Factors influencing movement patterns of keel-billed toucans in a fragmented tropical landscape in southern Mexico. Conserv. Biol. 15: 1789-1798.

Gray, M. A., Baldauf, S. L., Mayhew, P. J. and Hill, J. K. (2007) The response of avian feeding guilds to tropical forest disturbance. Conserv. Biol. 21: 133-141.

Greenacre, M. J. (1984) Theory and applications of correspondence analysis. London: Academic Press.

Groombridge, B. and Jenkins, M. (2002) World atlas of biodiversity. Berkeley: University of California Press.

Hasui, E., Gomes, V. S. de M. and Silva, W. R. (2007) Effects of vegetation traits on habitat preferences of frugivorous birds in Atlantic rain forest. Biotropica 39: 502-509.

Heinrich, R. (1995) Environmentally sound harvesting to sustain tropical forests. Commonwealth For. Rev. 74: 198-203.

Hill, J. K. and Hamer, K. C. (2004) Determining impacts of habitat modification on diversity of tropical forest fauna: the importance of spatial scale. J. Appl. Ecol. 41: 744-754.

Holling, C. S. (1992) Cross-scale morphology, geometry, and dynamics of ecosystems. Ecol. Monogr. 62: 447-502.

Huth, A., Drechsler, M. and Kohler, P. (2004) Multicriteria evaluation of simulated logging scenarios in a tropical rain forest. $J$. Env. Manage. 71: 321-33.

Jackson, S. M., Fredericksen, T. S. and Malcolm, J. R. (2002) Area disturbed and residual stand damage following logging in a Bolivian tropical forest. Forest Ecol. Manage. 166: 271-83.

Johns, A. D. (1988) Effects of selective timber extraction on rain-forest structure and composition and some consequences for frugivores and folivores. Biotropica 20 : $31-37$.

Krebs, C. J. (1998) Ecological methodology. New York: Benjamin Cummings.

Lambert, F. R. (1992) The consequences of selective logging for Bornean lowland forest birds. Phil. Trans. R. Soc. B. 335: Pp. 443-457.
Lindenmayer, D. and Fischer, J. (2006) Habitat fragmentation and landscape change. Washington D.C: Island Press.

Lindenmayer, D. and McCarthy, M. A. (2002) Congruence between natural and human forest disturbance: a case study from Australian montane ash forests. Forest Ecol. Manage. 155: 319-335.

MacArthur, R., Recher, H. F. and Cody, M. (1966) On the relationship between habitat selection and species diversity. Am. Nat. 100: 319-325.

Manning, A. D., Lindenmayer, D. B. and Nix, H. A. (2004) Continua and Umwelt: novel perspectives on viewing landscapes. Oikos 104: 621-628.

Mason, D. (1996) Responses of Venezuelan understory birds to selective logging, enrichment strips, and vine cutting. Biotropica 28: 296-309.

Mayer, S. (2000) Birds of Bolivia. Wierengastraat: Bird Songs International.

Messier, C. and Kneeshaw, D. (2003) Thinking and acting differently for sustainable management of the boreal forest. For. Chronicle 75: 929-938.

Mitchell, M. S., Rutzmoser, S. H., Wigley, T. B., Loehle, C., Gerwin, J. A., Keyser, P. D., Lancia, R. A., Perry, R. W., Reynolds, C. 1., Thill, R. E., Weih, R., White, D. and Wood, P. B. (2006) Relationships between avian richness and landscape structure at multiple scales using multiple landscapes. Forest Ecol. Manage. 221: 155-169.

Mostacedo, C. B. and Fredericksen, T. S. (1999) Regeneration status of important tropical forest tree species in Bolivia: assessment and recommendations. Forest Ecol. Manage. 124: 263-273.

Pariona, W., Fredericksen, T. S. and Licona, J. C. (2003) Natural regeneration and liberation of timber species in logging gaps in two Bolivian tropical forests. Forest Ecol. Manage. 181: 313-322.

Park, A., Justiniano, M. J. and Fredericksen, T. S. (2005) Natural regeneration and environmental relationships of tree species in logging gaps in a Bolivian tropical forest. Forest Ecol. Manage. 217: 147-257.

Petit, L. J., Petit, D. R. and Christian, D. G. et al., (1999) Bird communities of natural 
and modified habitats in Panama. Ecography 22: 292-304.

Pinard, M, Putz, F. (1996) Retaining forest biomass by reducing logging damage. Biotropica 28: 278-295.

Putz, F. E., Blate, G. M. and Redford, K. H. et al., (2001) Tropical forest management and conservation of biodiversity: an overview. Conserv. Biol. 15: 7-20.

Rametsteiner, E. and Simula, M. (2003) Forest certification - an instrument to promote sustainable forest management? J. Env. Manage. 67: 87-98.

Remsen, J. V., Hyde, M. A. and Chapman, A. (1993) The diets of Neotropical trogons, motmots, barbets and toucans. Condor 95: 178-92.

Ridgely, R. S. and Tudor, G. (1994) The birds of South America: The suboscine Passerines. Oxford: Oxford University Press.

Schemske, D. W. and Brokaw, N. (1981) Treefalls and the distribution of understory birds in a tropical forest. Ecology 62: 938-45.

Sekercioglu, C. H., Ehrlich, P. R., Daily, G. C., Aygen, D., Goehring, D. and Figeroa-Sandi, R. (2002) Disappearance of insectivorous birds from tropical forest fragments. Proc. Natl. Acad. Sci. USA 99: 263-67.

Stotz, D. F., Fitzpatrick, J. W., Parker, T. A. and Moskovits, D. K. (1996) Zoogeographic and ecological attributes of bird species breeding in the Neotropics. Pp. 118-291 in D. F. Stotz, J. W. Fitzpatrick, T. A. Parker and D. K. Moskovits, eds. Neotropical birds: Ecology and conservation. Chicago: University of Chicago Press.

Stratford, J. A. and Robinson, W. D. (2005) Gulliver travels to the fragmented tropics: geographic variation in mechanisms of avian extinction. Frontiers in Ecol. Env. 3: 91-98.

Terborgh, J., Robinson, S. K., Parker, T. A., Munn, C. A. and Pierpoint, N. (1990) Structure and organization of an Amazonian forest bird community. Ecol. Monogr. 60: 213-238.

Thiollay, J. M. (1992) Influence of selective logging on bird species-diversity in a Guianan rain-forest. Conserv. Biol. 6: 47-63. Thiollay, J. M. (1997) Disturbance, selective logging and bird diversity: A Neotropical forest study. Biodiv. and Conserv. 6: 1155-1173.

Timm, N. H. and Mieczkowski, T. A. (1997) Univariate and multivariate general linear models: Theory and applications. North Carolina: SAS Institute Inc.

Turner, I. M. (1996) Species loss in fragments of tropical rain forest: A review of the evidence. J. Appl. Ecol. 33: 200-209.

van Soest, D. (1998) Tropical deforestation: An economic perspective. Ridderkerk, The Netherlands: University of Groeningen and Labyrint Publications.

Verner, J. (1981) Measuring responses of avian communities to habitat manipulation. Pp. 543-47 in C. J. Ralph and J. M. Scott, eds. Estimating numbers of terrestrial birds. Kansas, Allen Press, Inc.

Verner, J. and Ritter, L. V. (1988) A comparison of transects and spot mapping in oak-pine woodlands of California. Condor 90: 401-419.

Waide, R. B. and Narins, P. M. (1988) Tropical forest bird counts and the effect of sound-attenuation. Auk 105: 296-302.

Whitman, A. A., Hagan, J. M. and Brokaw, N. V. L. (1998) Effects of selection logging on birds in northern Belize. Biotropica 30 : 449-457.

Wiens, J. (1992) The ecology of bird communities. Cambridge: Cambridge University Press.

Woltmann, S. (2003) Bird community responses to disturbance in a forestry concession in lowland Bolivia. Biodiv. and Conserv. 12: 1921-36.

Woltmann, S. (2005) Patterns of daily temporal variation in detectability of forest birds in Bolivia. Ornitologia Neotropical 16: $337-46$.

Wunderle, J. M., Henriques, L. M. P. and Willig, M. R. (2006) Short-term responses of birds to forest gaps and understory: An assessment of reduced-impact logging in a lowland Amazon forest. Biotropica 38: 235-255.

Wunderle, J. M., Willig, M. R. and Henriques, L. M. P. (2005) Avian distribution in treefall gaps and understorey of terra firme forest in the lowland Amazon. Ibis 147: 109-129. 
ADAM FELTON $^{1 *}$, JEFF T. WOOD, ANNIKA M. FELTON ${ }^{1}$, DAVID B. LINDENMAYER

Fenner School of Environment and Society, W.K. Hancock Building, The Australian National University, Canberra, Australia ozoo.

${ }^{I}$ Instituto Boliviano de Investigación Forestal (IBIF), Av. 2 de Agosto esq. Cuarto Anillo, Casilla Postal 6204, Santa Cruz de la Sierra, Bolivia.

BENNETT A. HENNESSEY

Armonía (Birdlife International partner in Bolivia), Avenida Lomas de Arena 400, Casilla 3566, Santa Cruz, Bolivia.

*Author for correspondence. e-mail: adam.felton@anu.edu.au

Received 16 December 2006; revision accepted 25 July 2007 